\title{
Indigência na atuação teatral
}

\section{Indigence in theatre acting}

André Luiz Lopes Magela ${ }^{1}$ 


\section{Resumo}

O presente artigo visa examinar consequências políticas provocadas por peças teatrais da Companhia Ueinzz de teatro, radicada em São Paulo, que tem em seu corpo de atuantes alguns usuários de atendimentos psiquiátricos. Dando atenção especial ao conceito de desoperamento, oriundo da obra de Maurice Blanchot, e seu desdobramento para o que chamamos de indigência, as reflexões aqui desenvolvidas tentarão mostrar como propostas de atuação teatral observadas na Ueinzz questionam e desestabilizam modos assimétricos de exercício de poder presentes na sociedade disciplinar, na de controle e na biopolítica, como investigados por Michel Foucault e seus comentadores.

Palavras-chave: Companhia Ueinzz; Biopolítica; Atuação teatral

\section{Abstract}

This article aims to examine political consequences caused by theatre plays of Companhia Ueinzz de teatro, based in São Paulo, which has in its acting crew some users of psychiatric services. It devotes special attention to the concept of unworking, obtained from texts written by Maurice Blanchot, and its unfolding into what we call indigence. The reflections developed here will try to show how proposals of theatre acting observed in Ueinzz question and destabilize asymmetric modes of exercise of power present in disciplinary society, control society and biopolitics, as investigated by Michel Foucault and his commentators.

Keywords: Companhia Ueinzz; Biopolitics; Theatre acting

ISSN: 1414.5731

E-ISSN: 2358.6958

${ }^{1}$ Prof. Dr. Universidade Federal São João del Rei (UFSJ), Minas Gerais, Brasil. andremagela@ufsj.edu.br 
A partir dos anos sessenta, notadamente com escritos de Gilles Deleuze e Félix Guattari, houve o aparecimento e disseminação de uma série de textos, atividades acadêmicas e iniciativas de intervenção conhecidas como "filosofias da diferença", que se conectaram com outros autores - Michel Foucault sendo o mais próximo e frequente - em desdobramentos chamados "estudos da subjetividade". Estas áreas imbricam questões relativas à arte, à política e à clínica social, visando à criação de estratégias eticoestéticas para modos de viver singulares e inventivos, que escapem às normatividades e homogeneizações da subjetividade ${ }^{2}$, majoritariamente através de ações micropolíticas: "À revelia das novas formas de gestão biopolítica da vida em escala planetária, que tendem galopantemente à homogeneização, vêm à tona por toda parte modos de existência singulares, humanos e não humanos." (Pelbart, 2014, p.250).

Quanto ao teatro, as reflexões dos estudos da subjetividade podem enfocar de maneira acurada as relações contemporâneas entre as artes cênicas e a política, numa hibridação de disciplinas e desenvolvimento de questões da biopolítica e da subjetividade. Este artigo quer se beneficiar deste cruzamento: o enriquecimento do campo teatral pelos estudos da subjetividade e o alargamento da perspectiva micropolítica pelo seu diálogo com o universo teatral. Para isso, vou me valer de análises de cenas teatrais onde podemos perceber algumas ocorrências de desestabilização de formas mais identificáveis de exercício assimétrico de poder.

O lugar adotado para estas análises são trabalhos cênicos da Ueinzz, companhia paulista de teatro onde aproximadamente metade de seus atores são usuários de atendimentos psiquiátricos. Coordenada por Peter Pál Pelbart, filósofo que se dedica aos estudos da subjetividade e tem examinado a biopolítica, esta companhia teatral trabalha desde 1997 e suas últimas criações foram Gravidade Zero: na órbita de Klonoa, no final de 2015, e Cais de ovelhas, em 2013 e 2014. Vou me deter particularmente sobre um trabalho imediatamente anterior a estes dois, Finnegans Ueinzz, que assisti muitas vezes, sendo alvo de análises detalhadas de minha parte, e pelo fato de que neste trabalho em específico identifico claramente relações entre a cena e alguns conceitos do campo filosófico aqui considerado.

\section{Análises sobre poder e subjetividade}

Em suas exposições sobre o poder, Michel Foucault descreveu os mecanismos da sociedade disciplinar, onde temos como modelo de exercício do poder a operação do panóptico (Foucault, 2004), arquitetura concebida por Jeremy Bentham inicialmente para utilização no sistema carcerário, onde aquele que vigia olha sem ser visto. O panóptico foi criado no século XVIII, dentro de um contexto específico, o da prisão, e está relacionado ao que Foucault denomina como "dispositivo":

Através deste termo tento demarcar, em primeiro lugar, um conjunto decididamente heterogêneo que engloba discursos, instituições, organizações arquitetônicas, decisões regulamentares, leis, medidas administrativas, enunciados científicos, proposições filosóficas, morais, filantrópicas. Em suma, o dito e o não dito

${ }^{2} O$ termo "subjetividade" é usado em outros campos e com muitas acepções, por vezes até divergentes e discordantes. No campo epistemológico aqui adotado, ela não diz respeito ao indivíduo, mas a modos de viver. 
são os elementos do dispositivo. O dispositivo é a rede que se pode estabelecer entre estes elementos. (Foucault, 1985, p. 244)

O panóptico instaura uma impressão de vigilância permanente, "mesmo se [a vigilância propriamente dita] é descontínua em sua ação" (Foucault, 2004a, p.166), o que constrói culpabilidade e obediência no vigiado. Este dispositivo constitui uma relação em que o enclausurado é "visto, mas não vê; [em que ele é] objeto de uma informação, nunca sujeito numa comunicação". Uma relação onde já podemos verificar um tipo de controle incipiente, ainda que este dispositivo seja distinguido conceitualmente como operação disciplinar. Como exemplo contemporâneo, podemos destacar os sistemas de câmeras de vigilância, onde não sabemos se somos vigiados ou não e, por isto, vigiamos nossas próprias ações: uma relação "que automatiza [...] o poder" (Foucault, 2004, p.167).

Deleuze, em 1990, comenta a passagem, durante o século XX, da disciplinarização dos corpos para o controle da população; controle que não se relaciona tanto ao desvio que se comete, mas ao que pode ser cometido - "vigiar os indivíduos antes mesmo que a infração seja cometida" (Foucault, 2008, p.107). Esta mudança é bem explanada por Giuseppe Cocco e Antonio Negri, amparados na descrição que Gilles Deleuze compõe sobre o que chama de sociedade de controle:

Simplificando, para Foucault a sociedade disciplinar é a sociedade na qual o comando social é construído através de uma rede ramificada de dispositivos que regem costumes, hábitos e práticas produtivas. [...] A regra provém do exterior, inscreve-se no sujeito através das instituições. Não é o que acontece no segundo tipo de sociedade. Eis como Deleuze a caracteriza: "Deve-se, ao contrário, compreender a sociedade de controle como aquela na qual os mecanismos de comando fazem-se cada vez mais democráticos, cada vez mais imanentes ao campo social, difusos no cérebro e no corpo dos cidadãos." Aqui a regra é cada vez mais interiorizada, tende para um estado de alienação autônoma. (Negri \& Cocco, 2005, p.214- 215)

A partir do momento em que a hegemonia dos meios de moldagem disciplinar do sujeito se torna consolidada e ao mesmo tempo insuficiente, percebemos novos modos de dominação, num paroxismo de invisibilidade dos mecanismos do poder. $\mathrm{Na}$ "sociedade de controle", que nos é mais contemporânea que a disciplinar, o sujeito não é mais confinado, mas sim levado a se tornar endividado (Deleuze, 2000, p.225), numa dívida que deve ser percebida de uma maneira existencialmente ampla, pois "a produção econômica é indissociável da produção e do controle da subjetividade e de suas formas de existência" (Lazzarato, 2011, p.58). Esta dívida funciona majoritariamente no constrangimento à produção e no desejo de se tornar produtivo e gerenciador de si, desembocando contemporaneamente num empresariamento generalizado na sociedade:

De fato, a "governamentalidade empresarial" que deve prevalecer no plano da ação do Estado tem um modo de prolongar-se no governo de si do "indivíduo -empresa" ou, mais exatamente, o Estado empreendedor deve, como os atores privados da "governança", conduzir indiretamente os indivíduos a conduzir-se como empreendedores. [...] A empresa é promovida a modelo de subjetivação: cada indivíduo é uma empresa que deve se gerir e um capital que deve se fazer frutificar. (Dardot \& Salas, 2016, p.378) 


\title{
Atuação teatral e normas
}

Mas estas distinções entre disciplina e controle configuram menos uma passagem do que uma acumulação, um acréscimo de mecanismos com eventual predominância, ainda hoje, de mecanismos disciplinares na contemporaneidade. Podemos considerar que nos processos de formação de atores operam estes modos de exercício de poder. O corpo, em ambos os campos, o considerado pela crítica do poder e o da formação teatral, é aquele "que deve ser formado, reformado, corrigido, o que deve adquirir aptidões, receber um certo número de qualidades, qualificar-se como corpo capaz de trabalhar" (Foucault, 2008, p.119).

\begin{abstract}
Nós queremos formar um ator ativo que disponha de uma formação geral válida e que seja capaz de efetuar desenvolvimentos cênicos complexos. Ao término de seus estudos, o estudante deveria ser capaz de reconhecer, de descrever um processo artístico e colocá-lo em relação com a realidade. Ao adquirir os métodos do ofício, o estudante aprende a analisar peças e papeis, assim como a ativar sua fantasia cênica. Claro que também se lhe ensina a compreender seu corpo e sua voz como ferramentas preciosas de trabalho e expressão. Enfim, é importante para nós que um ator seja capaz de se colocar a serviço não somente de um personagem ou de uma peça, mas de todo um conjunto, que ele de adapte bem à máquina teatral. (Schuler, 2003, p.105)
\end{abstract}

Nós queremos formar um ator ativo que disponha de uma formação geral válida e que seja capaz de efetuar desenvolvimentos cênicos complexos. Ao término de seus estudos, o estudante deveria ser capaz de reconhecer, de descrever um processo artístico e colocá-lo em relação com a realidade. Ao adquirir os métodos do ofício, o estudante aprende a analisar peças e papeis, assim como a ativar sua fantasia cênica. Claro que também se lhe ensina a compreender seu corpo e sua voz como ferramentas preciosas de trabalho e expressão. Enfim, é importante para nós que um ator seja capaz de se colocar a serviço não somente de um personagem ou de uma peça, mas de todo um conjunto, que ele de adapte bem à máquina teatral. (Schuler, 2003, p.105)

Estas colocações, realizadas em colóquio internacional de formação em teatro por Margarete Schuler, professora de teatro em Berlim, nos são tão interessantes quanto comuns. Mais precisamente: elas são significativas por serem comuns. Em outras palavras: não há nada de excepcional no que ela diz; suas demandas nos soam "normais", naturais. Porque, de fato, estes procedimentos são os que encontramos em qualquer escola, sendo ela para atores ou não: a medida da eficácia da escola é o quanto ela conseguiu adaptar seus alunos ao sistema a que se reporta. Há no discurso de Schuler a demanda de que o ator em formação deve se adequar a um sistema normativo, a "máquina teatral". Estes parâmetros ainda são os hegemônicos no imaginário e nos referenciais de escolas de ator da atualidade, mesmo que esta normatividade seja questionada por outros autores, ao questionarem esta exigibilidade de uma presença cênica previamente determinada, valorizando a presença performática do ator e denunciando "os discursos mistificado ᄀres sobre a presença de tal e tal ator, discursos que na verdade são normativos ('esse ator é bom, esse ator não')" (Pavis, 2008, p. 52-53). 
Considero ser importante, necessário, incentivar-se a desnaturalização de demandas excludentes por um tipo de ator que atenda a padrões de comportamento, um ator que necessariamente satisfaça a qualidades previamente determinadas como necessárias ao palco. O que tentamos distinguir neste projeto de ator e nesta estandardização de formação - nesta "adaptação à máquina teatral" - é sua adesão a um sistema de trabalho que seja hegemônico e que possa se pretender como a única maneira de se fazer teatro. $\mathrm{E}$, o que é mais importante do que possa parecer de imediato, é necessário colocar em evidência que modos de pensar o trabalho do ator são mais compatíveis com um sistema controlador ou disciplinar de produção do que formadores de artistas poderiam desejar ou assumir.

No caso da Companhia Ueinzz, estas demandas em termos de controle ou disciplina simplesmente não são atendidas. Deduzi, ao estar presente a ensaios da companhia, ao assistir a muitas apresentações e no contato com os integrantes, haver uma característica nos trabalhos da companhia: uma expansão criativa pessoal, que foi cultivada nestes vinte anos de trabalho. Uma exploração e desenvolvimento de uma intensa aceitação e assimilação das possibilidades criativas de cada um no modo como elas se apresentam, onde se permite e até se fomenta que se transgridam e se desprezem normas de atuação residentes em sistemas de formação atoral e de transmissão de saber cênico. Esta aceitação permite que os atores fiquem à vontade em seu trabalho, situação rara nos modos de produção teatral mais disseminados.

Flagrante sintoma disto, em Finnegans Ueinzz os atores que não estão em cena ficam à mostra, o que ocorre também em Cais de Ovelhas. Ao fundo do espaço de atuação há uma arquibancada: é como se fosse uma coxia em cena aberta. Nela, os atores ficam acomodados quando não estão nas cenas em evidência (as cenas dentro do roteiro da peça). Mas eles estão ali em cena também. Ficam sentados, cada um à sua maneira, conversam entre si, assistem às cenas, eventualmente saem e vão para o camarim (que fica ao lado deles) ou para trás do público, atravessando toda a lateral do espaço de atuação, às vezes para ir ao banheiro, se este fica atrás da plateia. Ou então, no caso mais extremo, entram em cena e fazem algo que se lhes mostre devido por algum motivo. Mas o que é mais relevante é a maneira como eles se valem desta arquibancada e do momento de não estarem atuando, ficando à vontade para fazer o que acharem necessário, ou ficarem, à nossa vista, descontraídos. E isto não atrapalha a cena - o que é de extrema importância; e todo esse campo cênico que a companhia e o espetáculo constroem é que permite isso.

Há também alguns fatos específicos, como serem colocados travesseiros, em cena aberta, para algumas atrizes mais idosas, num momento em que todos estão deitados no chão. A total falta de constrangimento em momentos em que claramente os atores não estão cumprindo com quesitos básicos da interpretação standard, como falar em volume audível, repetir o que é esperado, contracenar eficientemente (não encavalando as falas de um com o outro, por exemplo), não acrescentarem elementos em cena que não foram combinados com o diretor (alguns atores faziam isso frequentemente). Há alguns momentos em que a atuação é muito irregular, no sentido de haver claramente uma baixa de energia por uma aparente indisposição de algum ator; isso é absorvido e aceito. Em Gotham - SP, uma das primeiras peças da companhia, esta aceitação não era muito diferente, se tomamos o relato de Renato Cohen: 
Atores que largam sua posição para assistir a cena dos outros, e retomam na sequência dramática. Atores que realizam grandes monólogos e, também, que abandonam a cena sem completar suas frases. Essa estridente partitura de erros, de achados, de reinvenção do texto, vai se construindo na frente do público que está convocado como cúmplice desse novo entoar da "língua mágica". (Cohen, 2001, p.29)

Na peça Finnegans Ueinzz a voz dos atores frequentemente é baixa, por vezes inaudível, constituindo uma percepção sonora específica, um tipo de atenção determinado para receber esta paisagem sonora. A irregularidade do volume vocal acaba por compor um outro tempo - o tempo de silêncios, um ritmo específico à peça, compondo um tipo especial de atenção auditiva. Outro ponto de nota é o modo como, de uma maneira geral, alguns atores esperam em cena: como eles esperam a entrada de outros, como esperam por momentos chave ou deixas. É uma espera assumida, tranquila, que não tem a pressão de preencher um vazio ou de constituir um andamento cênico ritmicamente interessante para o espectador.

Parece-me que esta outra relação com o tempo teatral constitui também um confronto com a maneira como o tempo é vivenciado na sociedade contemporânea. Maria Rita Kehl, em importante estudo sobre a depressão, nota que a relação que o depressivo tem com o tempo é um lugar de resistência, na medida em que ele recusa a imposição de um tempo submetido às demandas frenéticas da produção atual, que se apropria do uso do tempo: o indivíduo moderno também não é senhor de seu tempo - a diferença é que ele já não sabe disso. Este ritmo de trabalho, regulado e otimizado, marca o passo de todas as instâncias de nossa vida. O lazer, por exemplo, o lugar que talvez devesse se opor ao labor, fica condicionado pela obrigação de sempre se "aproveitar bem o tempo", numa compulsão de desfrute que não difere em nada da cobrança por resultados de qualquer empresa:

Não me refiro ao ócio, essa forma de passar o tempo tão desmoralizada em nossos dias, mas às atividades de lazer, marcadas pela compulsão incansável de produzir resultados, comprovações, efeitos de diversão, que tornam a experiência do tempo de lazer tão cansativa e vazia quanto a do tempo da produção. Nada causa tanto escândalo, em nosso tempo, quanto o tempo vazio. É preciso 'aproveitar' o tempo, fazer render a vida, sem preguiça e sem descanso. (Kehl, 2009, p.124-125)

Como no modo contemporâneo de uso do tempo, a preparação de um trabalho teatral acaba por se submeter a esse imperativo de "fazer render", de tornar a peça interessante dentro de um ritmo e de um encadeamento que provoque este "efeito de diversão" na fruição do espetáculo. Na peça Finnegans Ueinzz, este imperativo não é acatado. O uso do tempo se libera deste constrangimento produtivo, abrindo-se a outras possibilidades que, inicialmente, podem ser recebidas, similarmente ao caso do depressivo, como um "mergulho angustiado e angustiante em um tempo estagnado, que lhe parece não passar" (Kehl, 2009, p.125). Cito como exemplo uma cena, "escafandro", onde há tempos e buracos que parecem permitir aos atores resolver suas falas, que têm um grande componente improvisacional.

Paradoxalmente, estas esperas dos atores da Ueinzz são muito expressivas. Uma atriz, na cena "kanji", em que realiza uma ação independente da ação de um outro ator, poderia começar sua ação antes da entrada dele, preenchendo assim um buraco rítmico e mantendo a condução do espetáculo para ser fruído pelo espectador 
(todas estas últimas considerações atendem a uma mecânica cênica convencional). Mas ela espera, assumidamente, a entrada deste - talvez até porque haja para ela uma necessidade de trabalhar com deixas claras - e só começa sua ação quando ele entra. Neste momento, o que temos sendo performado - e este é o paradoxo - é a espera. Um buraco, uma barriga rítmica que, por ser assumida, aceita, acaba sendo expressiva. Mas é um outro tipo de expressividade daquele que "faz render". A ideia na qual insisto é a de que não é o caso de estes atores merecerem cuidados e que o que temos é uma situação especial (no sentido da deficiência). Estes cuidados e esta outra maneira de ser que ocorrem na Ueinzz é que merecem ser vistos como uma proposta que possa influenciar outros grupos teatrais, outras formas de arte e de viver, outras formas de produzir subjetividade.

O que trataremos aqui é de possibilidades de contra-hegemonia que se dão, especificamente, por operações políticas relacionadas aos modos de atuação que destaco na companhia (a indigência, por exemplo, proposta na sequência argumentativa); e isto não exclui outras formas de luta ou institui que a técnica seja necessariamente opressora. Não se trata aqui de um libelo contra a técnica, mas de uma reflexão crítica à técnica como normatização.

\section{Desoperação}

Considerando as características do trabalho da Ueinzz antes mencionadas, podemos assumir que elas desestabilizam uma característica fundamental do exercício do poder. Trata-se do fato, já aqui mencionado, de que seu modo de operação é eminentemente produtivo, indutivo à produção:

\footnotetext{
O soberano só exerce, no caso, seu direito sobre a vida, exercendo seu direito de matar ou contendo-o; só marca seu poder sobre a vida pela morte que tem condições de exigir. O direito que é formulado como "de vida e morte" é, de fato, o direito de causar a morte ou de deixar viver. [...] Ora, a partir da época clássica, o Ocidente conheceu uma transformação muito profunda desses mecanismos de poder. O "confisco" tendeu a não ser mais sua forma principal, mas somente uma peça, entre outras com funções de incitação, de reforço, de controle, de vigilância, de majoração e de organização das forças que lhe são submetidas: um poder destinado a produzir forças, a fazê-las crescer e a ordená-las mais do que barrá-las, dobrá-las ou destruí-las. Com isso, o direito de morte tenderá a se deslocar ou, pelo menos, a se apoiar nas exigências de um poder que gera a vida e a se ordenar em função de seus reclamos. (Foucault, 1979, p.128)
}

Numa passagem do que antes era fazer morrer e deixar viver - ou seja, a punição, o poder de morte sobre os súditos - a forma de exercício do poder passa a ser predominantemente um fazer viver e deixar morrer. Isto ocorre basicamente por conta da ascensão do capitalismo e da necessidade cada vez maior de aproveitamento racional da mão-de-obra. Este fazer viver é o viver produtivo, dentro de termos aproveitáveis, capturáveis e colonizáveis num nível mais global, com um "mecanismo que permite extrair dos corpos tempo e trabalho mais do que bens e riqueza" (Foucault, 1985, p.187): 
[...] dizer que as relações de poder produzem é reconhecer que elas induzem efeitos que não são apenas de gestão, de limitação e eventualmente de sanção do real, mas que elas permitem ao contrário um superávit positivo de realidade - ou, para dizê-lo em termos mais ontológicos que políticos, uma produção de ser. Esta produção de ser afeta em primeiro plano os sujeitos que são apreendidos pelas relações de poder: ela é o que Foucault chamará em seguida de produção de subjetividade. (Revel, 2005, p.198)

A repressão deixa de ser eficaz e aproveitável, uma vez que assimilar e fomentar o desejo de produção dentro das normas é o que se torna mais atraente, por parte da burguesia, por exemplo: os poderes têm menos necessidade de nos reprimir do que de nos angustiar, ou, como diz Virilio, de administrar e organizar nossos pequenos terrores íntimos (Deleuze \& Parnet, 1998, p.75). Talvez possamos pensar que, de certa maneira, também o endividamento e o desejo de "trabalhar duro" para a posse de uma técnica de atuação não estariam distantes desta forma de controle pela dedicação à produção.

Em resumo: neste contexto biopolítico, uma das operações mais intensamente perpetradas pelos modos de exercício do poder é a incitação à vida (Foucault, 1979, p.128). Na verdade, a um tipo de vida direcionada à produção - a vida constrangida à subjetividade capitalística a que Guattari se referia (Guattari \& Rolnik, 2005): formas de viver adequadas à produção em formas de trabalho já estabelecidas, ao acúmulo de capital, ao consumo ${ }^{3}$.

Numa relação estreita com esta importância da produção e do trabalho, mesmo que por oposição simples (mas uma oposição que atingirá um ponto nevrálgico, estratégico), a morte ou a falta de produção, falta de uma produção esperada (o que é uma certa morte técnica), constroem um ponto cego para o poder, tornando-se uma possibilidade de linha de fuga. Como nos diz Michel Foucault, uma vez que o poder passa a vincular-se e a dirigir sua atenção à vida, este limite, que é a morte, lhe escapa (Foucault, 1979, p.130). Aludindo ao suicídio, Foucault nota nestas reflexões que, mesmo que já estivesse capturado teoricamente pela análise sociológica, este fenômeno não deixava (e ainda não deixa) de causar surpresa, de escapar à previsibilidade de eventos que é característica (ou ao menos pretendida) no poder instituído.

Mas talvez seja preciso que o modo de operação ou ocorrência desta morte, para que se configure uma resistência nesta sua relação com o biopoder, tenha características específicas. Para nos valer de um modo de morrer que nos interessa (sic), consideremos Peter Pál Pelbart (2009) quando este, amparado em Maurice Blanchot, avalia o que o autor de O Espaço Literário (Blanchot, 1987) denomina desoeuvrement.

Pelbart relê Blanchot quando este discorre sobre a "palavra poética", que remeteria a dois tipos de "noite": a primeira, de ausência e silêncio, onde "uma morte absoluta nos livraria do ser", e poderia nos permitir "escapar de seu domínio sufocante" (o domínio do ser) - e, por isso, ela traz certa segurança. A outra noite, que "pode ser um sussurro, o escoar da terra, um ruído apenas, incessante, do chão que se abre, do vazio que se torna presente", pode ser não-acolhedora, uma ameaça. Ela é a presentificação, num intenso gerúndio, da ausência da primeira noite. Ela é uma "morte que não morre": "É o "tudo desapareceu" aparecendo, a ausência da primeira noite se

${ }^{3}$ Noto que o consumo é produção também, como frequentemente enfatizam os teóricos do trabalho imaterial (Lazzarato, 1996) (Lazzarato \& Negri, 2001). 
presentificando. Aí o sono é substituído pelo sonho, a morte não é suficientemente morte, e o esquecimento torna-se esquecimento do esquecimento" (Pelbart, 2009, p.77).

Longe de ser um porto seguro, esta situação paradoxal, e tida como constituinte da obra (da palavra poética), é que é denominada como desoeuvrement (traduzida por Pelbart como desobramento) (Pelbart, 2009, p.79). Peter lembra que a palavra desoeuvrement em francês "significa, literalmente, ociosidade, preguiça, inação, isto é, um estado alheio ao trabalho e a seu fruto, que é a obra" (idem, p.80), atentando para o fato de que algo de caráter passivo poder ser justamente a operação da obra é um problema.

O que nos interessa aqui é perceber a proposta (seguindo e continuando a linha de raciocínio de Blanchot-Pelbart), relacionada a este conceito de desobramento, de que situações ou atitudes de inação, recusa, morte, anonimato, esgotamento ou indigência (este último termo identificado por Pelbart na obra de Blanchot como próximo ao neutro), são possibilidades do "fora", de escape da lei, do código, do ser, do controle. Em última instância (induzindo o raciocínio ao nosso interesse), situações de desmanche de um aparato produtivo, dos mecanismos relacionados a produzir mais e/ou melhor (na perspectiva de exercício do controle), a se dedicar mais à produção, à eficácia, à competência, à excelência em critérios hegemônicos. Em suma, são possibilidades de resistência política:

\footnotetext{
A passividade do morrer sem morte pode ser entendida como uma 'profissão de fé' antiontológica. 'A palavra do ser é palavra que sujeita, retorna ao ser, dizendo a obediência, a submissão', ao passo que seu contrário, a 'recusa do ser é ainda assentimento, consentimento do ser à recusa' - pela simples razão de que 'nenhum desafio à lei pode se pronunciar de outra forma que não em nome da lei que assim se confirma'. Blanchot propõe então que se abandone a esperança fútil de encontrar no ser um apoio para uma ruptura ou revolta, pois o ser é, em qualquer transcendência, a medida. Daí ser preciso esgotar o ser, levá-lo ao ponto em que cesse a diferença ser/não ser, verdade/erro, morte/vida. (Pelbart, 2009, p.81)
}

Esta recusa a um substrato determinado e seguro, no caso, o "ser", é uma oportunidade para que se coloque uma pergunta: como seria uma "indigência da atuação"? Como poderia se operar uma precariedade na atuação que abdicasse de um apoio ou uma reivindicação do ser no palco, da consistência cênica já instituída, ou da Ação (com A maiúsculo)? Um campo cênico que, por esta indigência e operando resistência às modalidades de solução cênica oferecidas para o teatro, proponha outras formas de utilizarmos este campo de experiência?

Tomemos o exemplo de Esperando Godot, escrita por Samuel Beckett. Nesta peça, a Ação é mais do que afrontada - ela é desacreditada. Não há contemplação das estruturas convencionais de enredo (início, meio e fim, com desfecho; algo que se possa apreender e controlar); não há super-objetivo, finalidade. Pior: há uma finalidade, mas ela é totalmente desacreditada no desenrolar da peça. Começando já com um final ("Nada a fazer"), Esperando Godot é um dos exemplos de que as peças de Beckett começam onde outras peças terminam, recusando o ciclo de anseios, objetivos, peripécias e desfechos - um ciclo de produção. Suas ações - não sendo psicológicas ou dramáticas - são espaciais, rítmicas (talvez também por isso a ne- 
cessidade de tantas rubricas para que se concretize a encenação), e não se sucedem causal ou progressivamente. O que há é um vazio construído por Beckett meticulosamente, como um teatro constituído por um, de certo modo, não-teatro.

Se considerarmos que a resistência é coextensiva ao poder que desestabiliza (Revel, 2008), notamos que nesta peça há um não-fazer, constituído pelo fazer ou por uma multiplicidade de fazeres, que não têm sua importância valorizada numa hierarquização - até a rubrica não é secundária. Há uma "desoperação" das ações até mesmo pela sua repetição. Construindo algo mais complexo do que um recipiente de vazios, Beckett forja variações, multiplicações, nuances de uma escassez que não deixa de estar presente em nenhum momento ou lugar da peça - ele não dá trégua ao "ser".

Mesmo o cenário é árido e a árvore apenas verdeja com duas ou três folhas. Um verdejar precário que afirma a aridez que grassa na peça; pois se a árvore estivesse sempre seca, poderíamos pensar que em algum outro momento ela talvez verdejasse radiantemente. Mas se ela verdeja assim, nem esta possibilidade deste outro verdejar (ilusório, desta maneira) é dada. Mas note-se que, mesmo vestidos precariamente, Vladimir e Estragon não são caracterizados nas rubricas como mendigos, mais uma vez no interior de um complexo é e não é que resiste à significação e a uma recepção da obra em modos de representação instituídos.

Sob certos aspectos, a peça praticamente se repete toda no segundo ato, o que atesta, mais uma vez, um caráter crônico naquilo, ou daquilo, que se passa no palco (num sentido similar ao de doença crônica: algo com o que temos de conviver sem solucionar ou nos livrar). $E$ isto questiona intensamente o que tomamos como novidade. Reforçando a vida como crônica, curiosamente, nenhum personagem morre nas peças de Beckett. Há a possível exceção de Nell em Fim de jogo, cuja última aparição se dá num estado de esvaecimento incômodo. Esvaecimento que não a impede de proferir sua última fala, para Clov: um emblemático "Deserte!" que Clov não entende, talvez porque tal pensamento não lhe seja categorizável ${ }^{4}$. Chafurda-se na angústia de um não saber, de uma permanência, de um constante em suspenso, de um motor rodando no vazio (um "nada a fazer" concreto, feito) que não recebe nem o gozo da morte. Na verdade, pela precariedade em que vivem, os personagens de Beckett, em sua maior parte, vivem num morrer crônico.

\section{Indigência em cena}

Uma das formas possíveis de constituição de ausência em peças teatrais é o silêncio. Na peça Finnegans Ueinzz existe uma sequência de duas cenas onde opera-se uma constituição de buracos e vazios, por meio de um anticlímax. Trata-se de "Mlle. Valérie" e "Valéria e Érika (onde é o lugar?)". Valéria já está em cena (pois foi a única atriz que não saiu da cena anterior) e simplesmente aguarda. Surgem, vindo do camarim, que fica ao fundo da cena, Roberto e Catherine. Ele entra com as mãos numa posição que reconhecemos como a de um cocheiro, segurando as rédeas e emitindo vários beijinhos para o cavalo, que é a atriz, e andam lateralmente

${ }^{4}$ No original em inglês a palavra "desert" pode ser ambígua (em inglês, ela significa o substantivo "deserto" e o verbo "deserte"), deixando realmente margem para que Clov a entenda como "deserto" - que é o que ocorre na peça. 
pelo fundo, da esquerda até o meio. Eles ficam durante um curto tempo andando parados (mexendo-se como se estivessem se deslocando, mas sem sair do lugar); então param sincronamente de se mover e desmontam um pouco esta carruagem imaginária. Roberto vem até o meio da cena, onde está Valéria em espera, e a toma pela mão de maneira polida, falando-lhe "sua carruagem está pronta". Leva-a até a "carruagem" ao fundo do palco, coloca-a sentada num banco entre ele e o cavaloCatherine e começa a mimar, por um breve tempo e sem se deslocar, o deslocamento da carruagem, junto com o cavalo. Param e ele a pega, trazendo-a até o público, quando anuncia: "Senhoras e senhores, Mademoiselle Valérie". Outra atriz, Érika, vem se aproximando, vindo do fundo, com uma cadeira nas mãos. O cocheiro deixa Mademoiselle Valérie com Érika e dirige-se ao fundo para pegar o cavalo, saindo com a carruagem pela direita até a frente do espaço cênico, continuando seu caminho até a direita da plateia e saindo pela traseira das cadeiras onde o público frontal se senta (a disposição do público é tri-frontal: há público frontal e lateral, formando uma plateia em "U"). Iza, uma outra atriz, vem em silêncio do fundo com eles, já entrando no espaço de atuação, e fica à direita no proscênio, à espera. Enquanto a carruagem sai, sem chamar muito a atenção do público, ocorre um jogo em que Érika está a oferecer a cadeira para Mademoiselle Valérie, que parece não se decidir onde sentar-se. Elas fazem isso de uma maneira muda e sem muitos movimentos. Após duas ou três tentativas de se posicionar a cadeira, Valéria senta-se e Érika, às suas costas, enfia uns quatro palitos japoneses, retirados do próprio cabelo, no cabelo de Valéria, vindo à sua frente e aprovando o que fez meneando a cabeça. Valéria levanta-se, Érika pega novamente a cadeira e vai até o camarim ao fundo, saindo de cena. Valéria, então, aguarda o momento de ir ter com Iza, que entrou e aguarda no proscênio, à direita. Entra a música da próxima cena ("Monet", cena bastante lírica, onde esta atriz fala um texto ao microfone, com a música ao fundo) e acaba uma instância ou campo que, considero, foi constituída por estas duas cenas que descrevi, "Mlle. Valérie" e "Valéria e Érika (onde é o lugar?)".

Esta instância é o anticlímax a que me referi: um andar sem se deslocar, ações que não produzem uma outra coisa senão elas mesmas, uma atitude pouco vigorosa e ligada ao menor, à espera. Os inacabamentos que ocorrem em muitos momentos na peça também geram este não-clímax (não gozo?). Não me refiro agora a um acabamento cênico (o que também há na peça, e muito: a falta de acabamento), mas a uma inconclusão que sabota as expectativas de conclusão. A cena de Mademoiselle Valérie é um nenhum lugar para lugar nenhum.

A precariedade pode se dar também sob outros aspectos. O fato desta peça ancorar-se basicamente no trabalho dos atores, quase sem recorrer a outros recursos cênicos como uma música e cenografia sofisticadas, também confere um caráter de simplicidade ao espetáculo. E é preciso notar que a atuação deles já frustra muitas demandas convencionais...

Realmente, há a sensação constante no espetáculo de que tudo está "por um triz" (retomando um termo utilizado por Pelbart sobre a companhia), que tudo feito pelos atores está sendo improvisado ou sendo esquecido, resolvido, na medida de um possível, na hora. Existe um caso especial, que é a cena "paquita", performada, já quase ao final da peça, pelos atuantes Valéria e Eduardo. Nesta cena, que é bem cur- 
ta, eles vêm, após um blackout, do fundo da cena até o lugar mais à frente da plateia dianteira (lembremos do formato em "U", tri-frontal). $O$ ator, que conduzia a atriz por uma mão e segurando um caderno na outra, aguarda mais atrás dela, que se senta com os joelhos no chão e as mãos sobre as pernas. Valéria começa, com uma voz muito baixa e hesitante, os olhos sempre dirigidos para baixo, eventualmente parecendo ter de recuperar na memória o texto, a falar sobre um sonho que tinha quando era mais nova. Ela diz que seria difícil realizá-lo, porque teria de aprender várias coisas, como falar outras línguas, e outras poucas descrições deste sonho. Por fim, ela diz que o sonho era ser paquita da Xuxa5. No fim de seu texto, sinaliza abaixando sutilmente a cabeça e Eduardo vem até ela e lhe dá o caderno, no qual ela rapidamente escreve algo. Ele a ajuda a levantar-se e os dois saem para o fundo do espaço cênico.

O texto varia muito de dia para dia, e esta é a questão que agora gostaria de examinar. Como já disse, a cena chama-se "paquita" e podemos saber isso pelo roteiro que é mostrado à platéia, escrito em uma das paredes do espaço. Mas a atriz, cuja fala já parece sair à pena de seus lábios, bem entrecortada, com uma respiração que parece precisar pegar fôlego a cada fala, arrumando o corpo (tal dificuldade não é respiratória, mas sim como se the fosse difícil falar aquelas palavras), simplesmente abandona, a cada dia num ponto diferente, o curso desta fala. Nas apresentações assistidas por mim (dezesseis ao todo), ela raramente chegou ao fim da fala para explicitar que seu sonho era ser paquita da Xuxa. Por vezes simplesmente ela parava de falar no meio da fala, deixando um vazio maior na cena.

Avaliando todos os dias de apresentação, o que fica para mim como espectador é uma ostensiva desistência. Uma desistência transversal (pela maneira como o texto é emitido, permeando toda a cena) e explícita (pelo abandono sumário da cena), percebida mesmo por quem assiste apenas a um dia da peça. E a relação entre o que ela diz e/ou não diz (haver a palavra paquita ou não em sua cena, correspondendo satisfatoriamente ou não ao nome da cena que é designado num roteiro escrito na parede que identifica para o público o nome e ordem das cenas) se explicita como este abandono. Alguns espectadores, em conversas travadas comigo, até pelo fato de que a cena gera neles uma intensa comoção, se perguntaram "por que ela não faz até o fim?". Fica por vezes a suspeita de que seja esquecimento do texto; suspeita de que não compartilho. Na verdade, eu não soube (pelos critérios convencionais de verificação) por que motivo ela não termina, na maior parte das vezes, o que é esperado numa expectativa senso comum do que seria a cena "completa". Confesso que, como espectador que aprecia o espetáculo e já viu esta cena com todas as falas esperadas por mim, sou frustrado em minhas expectativas quando ela não fala tudo.

Mas será que é isso mesmo? Uma cena completa é uma cena que tem todas as falas que alguém - quem? - espera? É este cumprimento que define o completo acontecimento teatral?

De todo modo, o que relatei torna a cena muito comovente. E talvez fosse mais frustrante se ela sempre falasse tudo.

Gostaria de refletir sobre a performação desta cena por esta atriz. A suposta cena completa deveria ser repetida todos os dias com um roteiro específico que,

${ }^{5} \mathrm{~A}$ apresentadora de TV de programas infantis, que se valia da ajuda de várias adolescentes loiras com um porte físico padrão - as paquitas - para controlar as crianças presentes em seu programa. 
mesmo com as variações da performatividade diária, variações humanas comuns no teatro em temporada, se restringiria a uma determinada faixa de sentido. Mas a atriz, ao terminar esta cena dentro de outros critérios que não aqueles que são esperados numa maneira convencional de ensaiar e executar o que foi combinado, coloca em xeque este tipo de modo de se dar a cena e abre caminho para um outro tipo de acontecimento teatral. Desobrando esta cena, a atriz coloca o espectador num lugar diferente de uma recepção de algo acabado e que será apresentado como foi previamente preparado.

Não só pela carga de intensidade que a recepção da cena confere, mas por efetivamente operar um desobramento, essa desistência é extremamente expressiva; ela salta aos olhos e produz algo para o espectador, o que é um paradoxo. É uma retirada da atriz, uma deserção que insere alguma coisa ali no espaço cênico, uma ausência que presentifica alguma coisa, algo que só se exprime por esse abandono da atriz. A deserção consegue operar um desoeuvrement da cena, talvez aquela "morte que não morre".

Lembrando de Pelbart, quando este refere-se à "vida em estado de variação, modos 'menores' de viver que habitam nossos modos maiores e que no palco ganham visibilidade cênica, legitimidade estética e consistência existencial" (Pelbart, 2003, p.150), é mister dizer que o setting teatral, como nas outras situações da peça, é de fundamental importância para que a presença desta ausência se opere. É só pelo fato de se constituir uma peça teatral e um campo cênico que esta deserção, este ausentar-se, tem valor e efeito.

Este fato é de extrema importância sob a perspectiva do campo político-cênico examinado neste artigo, o da biopolítica e estudos da subjetividade. A importância do trabalho da Ueinzz é que suas operações político-cênicas, mesmo estas de indigência, que resvalam o negativo, estão num terreno de afirmação intensa. Quando enfatizo a importância de eles estarem realizando a indigência dentro do teatro, dentro de um campo cênico intensamente instaurado, é essa positividade que está sendo levada em conta. Essas operações, assim, se tornam propostas consistentes de uma produção de subjetividade que não nega a vida, mas que nega especificamente a sua captura.

Aquela renúncia ao "ser" se mostra para nós como uma renúncia aos modos de subjetividade capturados: os oferecidos e/ou impostos como legítimos. $O$ "ser" criticado aqui é o ser posto em visibilidade pelo poder. Mas esta renúncia não é uma oposição à vida. A realização cênica da Ueinzz, como proposta de outros modos de temporalização, de produção em geral, de produção de subjetividade, se alia a formas de luta singulares que, pela sua renúncia às relações capturadas, conseguem sabotá-las ao esvaziá-las, produzindo outras formas, e de outras formas. Esta renúncia dentro do palco consegue sabotar dispositivos que exercem um

[...] processo de valorização (de subsunção) que coloca nossas vidas inteiras para trabalhar, [forjando uma] nova forma de escravidão [que] visa na realidade a governar o que, na outra ponta, se constitui como atividade livre e criativa de singularidades que se tornam produtivas independentemente da relação de capi $\neg$ tal. (Cocco, 2009, p. 133) 
Há um confronto entre esta proposta de indigência da atuação e uma atuação padrão que denote uma competência consagrada. E a maneira proposta de fazer arte, de viver, explícita no trabalho da Ueinzz é uma abertura às suscetibilidades e uma não exigência de virtuosismo infalível. São erros que acertam.

Sim, sob o ponto de vista da repetição, de poder ser comparada em termos de identificação de um dia para outro, as peças são bem imprevisíveis e chegam a configurar uma situação em que nem seja o caso de se avaliá-las por esse critério - cada dia é muito diferente. Mas a pergunta que se coloca é: a precisão e a qualidade são a capacidade de (se) repetir exatamente? Ser preciso, rigoroso, competente é estar exatamente dentro dos critérios pré-definidos, fazer o que se espera que seja feito? Seria estar exatamente na norma, corresponder a ela?

O teatro convencional costuma se ancorar muito sobre a capacidade de se repetir de uma apresentação a outra. Se um evento cênico não se repete e é diferente a cada dia, já é enquadrado de outra maneira e é chamado de performance, por exemplo. Yan Michalski era conhecido, dentre outras especificidades de seu grande trabalho dentro do teatro brasileiro, por se dispor a assistir mais de uma vez a uma peça teatral quando exercia seu papel de crítico. Os críticos teatrais mais convencionais, por padrão, vão a apenas uma apresentação e classificam a peça na suposição e no conhecimento tácito de que aquilo que veem em um dia é sempre daquela maneira. Podemos supor, então, que este procedimento tem por premissa que a peça deve ser sempre assim; que ela deve ser sempre igual em todos os dias, pois caso contrário esta crítica realizada em apenas um dia não teria validade. Ou teria de ser realizada mais de uma vez, com desdobramentos, consequências que sugerem uma complexidade maior, desejável inclusive, na relação ente crítica e realizadores.

Coloco em relevo, nos eventos cênicos circunscritos ao trabalho da Ueinzz, as características consideradas como desestabilizadoras e que vão contra a norma. Mas a potência desta desestabilização reside também em sua capacidade de se articular com o instituído, com formas constituídas, com algumas permanências, com o já construído e com o reconhecível. Observo, dentro desta perspectiva, um ponto interessante em Finnegans Ueinzz, que é o irrestrito respeito a pontos-chave da peça, principalmente ao roteiro. Estes pontos-chave nunca são desrespeitados: para deixar claro o que digo, noto que o ator da cena "Ulisses", por exemplo, mesmo em uma virtual falta de limites, nunca, por exemplo, deixou de entrar em suas deixas determinadas pelo roteiro da peça. Aliás, nenhum ator fez isso em nenhum momento, nem por alguma variação ou falha, nem propositalmente. Pode parecer que isso não é importante, mas essa seria talvez a primeira forma a ser pensada como desestabilizadora da cena: não entrar nela. Outro fato é que quem já atuou em peças teatrais sabe que as entradas de cena são os momentos de conexão mais delicados em um espetáculo, e são vistos por nós, atores e diretores, com muito zelo.

Mas outros pontos-chave são desrespeitados na Ueinzz: falas ou eventos parciais que eventualmente não acontecem e em que simplesmente continua-se o trabalho (exemplos são a cena "paquita", a história do cego do Tatuapé - cuja narração por vezes mal acontece -, o personagem Ulisses que muitas vezes não é nem mencionado na cena homônima). Há uma contradição nesta abertura interna a cada cena, no fato de que elementos importantes, como a história do cego do Tatuapé ser contada 
inteira pela sereia ou a explicitação de que o que Valéria queria era ser paquita, não acontecerem; no fato de não haver a exigência (pelo menos não haver da mesma maneira) de que coisas interessantes que os atores fazem sejam fixadas. Porque isto pode ser visto como uma desvalorização do trabalho de ensaio e de criação.

Alguns diretores parecem se frustrar quando o ator não faz algo que eles, com sua experiência e sensibilidade, veem que pode ser feito; ou quando o ator não repete algo que se mostra interessante e que foi feito anteriormente. Grande parte da literatura e dos treinamentos de atuação têm como principal objetivo garantir a repetição fiel da atuação entre um dia e outro de apresentação da peça; e desejavelmente com o frescor da primeira vez (o momento do "achado"). Além disto, o trabalho clássico do diretor ao organizar uma peça inclui a fixação de pontos-chave e modos-chave de atuar para proteger o ator dele mesmo - de seus esquecimentos, de sua incompetência em relação a uma capacidade que ele teve em um ensaio... O que o ator pode fazer de bom é, assim, o que ele deve fazer.

Diferentemente, a clara proposta que há na Ueinzz é de entrar-se existencialmente em contato com acontecimentos que se produzirão sem estas garantias de repetição do que, em algum momento, por alguns critérios, se mostrou como o bom. O que parece ser buscado na Ueinzz, mesmo que articuladamente com um roteiro e com uma estrutura, é o bom que se mostra a cada instante, dentro de uma lógica de troca de afetos, e não de controle prévio. Esta renúncia ao controle parece sabotar também uma concepção de profissionalismo teatral que considera o espetáculo um produto com qualidade garantida, a ser repetida a cada dia; questionamento que não é estranho ao próprio meio do teatro:

Para Grotowski, nem a perfeição técnica ou o treinamento intensivo podiam levar ao ato, nem esse ato, uma vez realizado, podia ser reconstruído como meio, como truque. E era aí que Grotowski via a falência do profissionalismo, para ele espremido exatamente entre os pilares da técnica e dos efeitos. Grotowski via no profissionalismo - e em sua própria trajetória profissional $\neg$ - um tanto de manipulação e um tanto de utilitarismo, ligado à produção de um espetáculo, que era necessário abandonar. (Lima, 2008, p.220)

\section{Disseminação}

Pelbart comenta a possibilidade de outros modos de vida e de profissionalismo teatral que são propostos pelas atitudes de alguns atores nas peças da companhia Ueinzz. Temos o ator que se recusa a entrar em cena porque aquele será o dia da sua morte, ou o guia que, em um dia de apresentação, leva todos os atores, em cena, a uma trajetória inesperada e finalmente a um beco sem saída em pleno transcorrer da peça. Mais que transtornos, tais ocorrências abrem brechas de percepção para a platéia:

Se é a subjetividade que ali é posta a trabalhar, o que está em cena é uma maneira de perceber, de sentir, de vestir-se, de mover-se, de falar, de pensar, mas também uma maneira de representar sem representar, de associar dissociando, de viver e de morrer, de estar no palco e sentir-se em casa simultaneamente, nessa presença precária, a um só tempo plúmbea e impalpável, que leva tudo extremamente a sério e ao mesmo tempo "não está nem aí", [...]. O cantor que não canta, quase 
como Josefina, a dançarina que não dança, o ator que não representa, o herói que desfalece, o imperador que não impera, o prefeito que não governa - a comunidade dos que não têm comunidade. (Pelbart, 2003, p. 149)

Associo os modelos de competência e eficácia na atuação com a cultura capitalística, com o paradigma moderno de fomento à produção e ao individualismo, com o controle e com uma normatização no teatro. Nestas alternativas conceituais e cênicas aos paradigmas hegemônicos, várias formas de produção que fogem à norma da excelência, da eficácia, do extraordinário, do racionalismo e do controle nos interessam:

\footnotetext{
As sociedades "arcaicas" que ainda não incorporaram o processo capitalístico, as crianças ainda não integradas ao sistema, ou as pessoas que estão nos hospitais psiquiátricos e que não conseguem (ou não querem) entrar no sistema de significação dominante, têm uma percepção do mundo inteiramente diferente da que se costuma ter da perspectiva dos esquemas dominantes. Isso não quer dizer que a natureza de sua percepção dos valores e das relações sociais seja caótica. Correspondem a outros modos de representação do mundo, sem dúvida muito importantes para as pessoas que deles se servem para poder viver, mas não só para elas, sua importância poderá se estender a outros setores da vida social, numa sociedade de outro tipo. (Guattari \& Rolnik; 2005, p. 35)
}

Estas formas de viver e produzir associadas à criação da Ueinzz dão corpo à visão de política no teatro que damos a este trabalho. Um dos atores da companhia, que performa a cena "Severino", que no primeiro dia em que o vi ensaiando ficava apenas deitado num sofá quando não estava em cena, tem características que compõem uma aparência associada a um usuário de atendimento psiquiátrico (as mãos trêmulas, um olhar específico, movimentos lentos). Este ator (contraditoriamente usando um capacete de trabalhador nesta cena), por sua aparência, nas perspectivas hegemônicas está fora de uma sociedade de produção. Ele não se opõe explicitamente a ela (isso é importante notar), apenas está fora dela.

Mas não exatamente fora, porque, afinal, ele é ator e participa de uma peça de teatro inserida nas produções cênicas da cidade de São Paulo e do Brasil (por exemplo, já foram profissionalmente à Alemanha, à França e realizaram apresentações na Finlândia, atividades tidas como sintoma de sucesso no Brasil) e protagoniza duas cenas de grande impacto (uma delas, a de abertura da peça Finnegans). Ele e outros atores da Ueinzz, com suas peculiaridades, produzindo a cena, acabam por propor, em ato, uma indigência da atuação em relação aos critérios de competência, eficácia e produtividade comumente aplicados ao ator. Uma indigência operativamente política, que transborda do palco para a vida cotidiana, propondo outras formas de fazer teatro e viver.

\section{Referências}

BLANCHOT, Maurice. O Espaço Literário. Rio de Janeiro: Rocco, 1987.

COCCO, Giuseppe. MundoBraz - O devir-mundo do Brasil e o devir-Brasil do 
mundo. Rio de janeiro: Record, 2009.

COHEN, Renato. Teatro del Inconsciente - Procesos Creativos - Compañía Tea tral Ueinzz. In: Teatro al sur No 20. Buenos Aires: Teatro al Sur, 2001.

DARDOT, Pierre \& LAVAL, Christian. A nova razão do mundo - Ensaios sobre a sociedade neoliberal. Belo Horizonte: Boitempo Editorial, 2016.

DELEUZE, Gilles. Conversações. São Paulo: Editora 34, (1992) 2000.

DELEUZE, Gilles \& PARNET, Claire. Diálogos. São Paulo: Escuta, 1998.

FOUCAULT, Michel. História da Sexualidade I - A vontade de saber. Rio de Ja neiro: Graal, 1979.

FOUCAULT, Michel. Microfísica do Poder. São Paulo: Graal, 1985 (2007).

FOUCAULT, Michel. Vigiar e Punir - O nascimento da prisão. Petrópolis: Vozes, 2004.

FOUCAULT, Michel. A Verdade e as formas jurídicas. Rio de Janeiro: NAU Editora e PUC - Rio, 2008.

GUATTARI, Félix \& ROLNIK, Suely. Micropolítica. Cartografias do desejo. Petró polis: Vozes, 2005.

KEHL, Maria Rita. O tempo e o cão - a atualidade das depressões. São Paulo: Boitempo Editorial, 2009.

LAZZARATO, Maurizio \& NEGRI, Antonio. Trabalho imaterial : formas de vida e produção de subjetividade. Rio de Janeiro: DP\&A, 2001.

LAZZARATO, Maurizio. Immaterial Labor. In: HARDT, Michael \& VIRNO, Paolo. Radical thought in Italy - A potential politics. Minneapolis - USA: University of Minnesota Press, 1996.

LAZZARATO, Maurizio. La fabrique de l'homme endetté - Essai sur la condition néolibérale. Paris : Éditions Amsterdam, 2011.

LIMA, Tatiana Motta. Les Mots Pratiqués: relação entre terminologia e prática no percurso artístico de Jerzy Grotowski entre os anos de 1959 e 1974. Rio de Ja neiro: Tese de doutorado - PPGT / UNIRIO - Universidade Federal do Estado do Rio de janeiro, 2008.

NEGRI, Antonio \& COCCO, Giuseppe. Glob(AL): biopoder e lutas em uma Amé rica Latina globalizada. Rio de Janeiro: Record, 2005. 
PAVIS, Patrice. A Análise dos Espetáculos. São Paulo: Perspectiva, 2008.

PELBART, Peter Pal. Da clausura do fora ao fora da clausura - loucura e desra zão. São Paulo: Brasiliense, 1989 (2009).

------. Vida Capital. Ensaios de biopolítica. São Paulo: Iluminuras, 2003.

PELBART, Peter Pál. A arte de instaurar modos de existência que 'não existem'. In: Bienal de São Paulo. (Org.). Como falar de coisas que não existem. 1ed. São Paulo: Bienal de São Paulo, 2014, v. 1, p. 250-265.

REVEL, Judith. Experiénces de la pensée - Michel Foucault. Paris : Bordas, 2005.

SCHULER, Margarete. Former um acteur actif. In: FÉRAL, Josette (org.). L'école du jeu - Former ou transmettre... les chemins de l'enseignement théâtral. SaintJean-de-Védas: L'Entretemps, 2003.

Recebido em: 30/04/2016

Aprovado em: 02/06/2016 